\title{
A NEW VALIDATED STABILITY INDICATING RP-HPLC METHOD FOR ESTIMATION OF PIMECROLIMUS IN BULK AND TOPICAL FORMULATIONS
}

\author{
Sreedhar Lade ${ }^{*}$ and Y. Rajendra Prasad ${ }^{2}$ \\ ${ }^{* 1}$ College of Pharmaceutical Sciences, Acharya Nagarjuna University, \\ Nagarjuna Nagar, Guntur-522510 A.P., India \\ 2University College of Pharmaceutical Sciences, Andhra University, \\ Visakhapatnam-530 003, A.P., India
}

* Corresponding author e-mail: sreedharlade7@gmail.com

\begin{abstract}
:
A new simple, precise, selective, accurate and rapid reverse phase high performance liquid chromatographic stability indicating method had been developed and validated for quantitative determination of Pimecrolimus in bulk and pharmaceutical dosage form. The chromatographic separation was achieved with Inertsil ODS C-18, $(150 \times 4.6 \mathrm{~mm})$ and $5 \mu \mathrm{m}$ particle size column. The optimized mobile phase consists of phosphate buffer, $\mathrm{pH}$ adjusted to 4.0 with $o$-phosphoric acid and Acetonitrile in the ratio of $(55: 45 \% \mathrm{v} / \mathrm{v})$. The flow rate was $1.0 \mathrm{~mL} / \mathrm{min}$ and eluents were detected at $258 \mathrm{~nm}$ using PDA detector. The retention time of Pimecrolimus was found to be 2.970 minutes. The percentage recoveries for three molecules were found to be in the range of $99-101 \%$. The calibration curve was constructed between peak area vs concentration and demonstrated good linearity in the range of $5-30 \mu \mathrm{g} / \mathrm{ml}$ for Pimecrolimus. Degradation studies were studied for Pimecrolimus under various stress conditions such as acid hydrolysis, base hydrolysis, oxidation, thermal, photochemical and UV. All the degradation peaks were resolved effectively using developed method with different retention times. The developed method was validated according to ICH guidelines. As the method could effectively separates the degradation products from active ingredient, it can be used for routine analysis of drug both in bulk and pharmaceutical dosage form.
\end{abstract}

Key words: Pimecrolimus, Acetonitrile, Buffer, RP-HPLC.

\section{INTRODUCTION:}

Pimecrolimus is a white to off-white fine crystalline powder. It is soluble in methanol and ethanol and insoluble in water. Pimecrolimus, like Tacrolimus, belongs to the ascomycin class of macrolactam immunosuppressives, acting by the inhibition of T-cell activation by the calcineurin pathway and inhibition of the release of numerous inflammatory cytokines, thereby preventing the cascade of immune and inflammatory signals ${ }^{[1]}$.

Pimecrolimus has a similar mode of action to that of Tacrolimus but is more selective, with no effect on dendritic (Langerhans) cells[2]. It has lower permeation through the skin than topical steroids or topical Tacrolimus ${ }^{[3]}$,

\section{How to cite this article:}

Sreedhar lade and Y. Rajendra Prasad. A new validated stability indicating RP-HPLC method for estimation of pimecrolimus in bulk and topical formulations. Int. J. Adv. Pharm. Biotech., 2015; 1(1): 33-44. although they have not been compared with each other for their permeation ability through mucosa. In addition, in contrast with topical steroids, Pimecrolimus does not produce skin atrophy ${ }^{[4]}$. It has been proven to be effective in various inflammatoryskin diseases, e.g., seborrheic dermatitis[5], cutaneous lupus erythematosus ${ }^{[6]}$ oral lichen planus[7], vitiligo ${ }^{[8]}$ and psoriasis ${ }^{[9,10]}$. Tacrolimus and Pimecrolimus are both calcineurin inhibitors and function as immuno suppressants[11]. The compound inhibits calcineurin, a phosphatase that is essential for the translocation of the transcription factor, nuclear factor of activated T-cells, into the cell nucleus. 
As a consequence, Pimecrolimus inhibits the transcription and release of inflammatory cytokines and of other proinflammatory mediators in T-cells and mast cells ${ }^{[12]}$. Pimecrolimus cream $1 \%$ is registered worldwide for the topical treatment of patients with mild to moderate atopic eczema (atopic dermatitis) and has been shown to be effective also in other inflammatory skin disorders such as allergic contact dermatitis and seborrheic dermatitis[13-14].

Literature survey reveals that no RP-HPLC method was developed for estimation of Pimecrolimus in Pimecrolimus 1\% cream. Therefore, the main aim of the present work is to develop and validate novel RP HPLC method for estimation of Pimecrolimus in bulk and pharmaceutical dosage forms. Hence, it has driven the authors to develop a method which is new, simple, precise, and accurate for the determination of Pimecrolimus in its pharmaceutical dosage form.

Each gram of ELIDEL Cream, 1\% [Valeant Bermuda] contains $10 \mathrm{mg}$ of Pimecrolimus in a whitish cream base of benzyl alcohol, cetyl alcohol, citric acid anhydrous, mono-and diglycerides, oleyl alcohol, propylene glycol, sodium cetostearyl sulphate, sodium hydroxide, stearyl alcohol, triglycerides, and water.

Chemically, Pimecrolimus is $(1 \mathrm{R}, 9 \mathrm{~S}, 12 \mathrm{~S}$, 13R,14S,17R,18E,21S,23S,24R,25S,27R)-12-

[(1E)-2-\{(1R,3R,4S)-4chloro-3-methoxy cyclohexyl\}-1-methylvinyl]-17-ethyl-1,14dihydroxy-23,25-di-methoxy- $13,19,21,27-$ tetramethyl 11, 28- dioxa-4-aza-tricyclo [22.3.1.04,9] octacos-18-ene-2,3,10,16tetraone. The compound has the empirical formula $\mathrm{C}_{43} \mathrm{H}_{68} \mathrm{CINO}_{11}$ and the molecular weight of $810.47^{[15]}$.

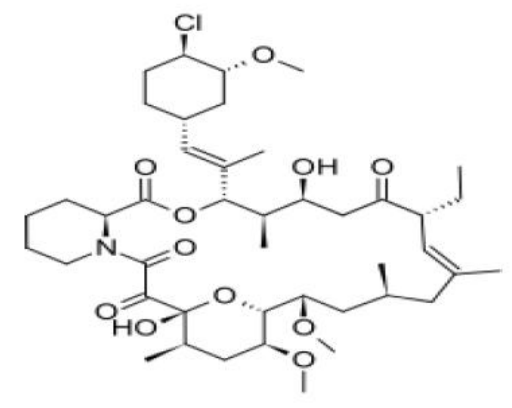

Fig. 1: Structure of Pimecrolimus

\section{MATERIALS AND METHOD:}

\section{Chemicals and solvents:}

Pimecrolimus was obtained as gift sample from Spectrum Pharma Research Solutions, Hyderabad, India. The commercial Pharmaceutical Preparation Elidel cream with $1 \% \mathrm{w} / \mathrm{w}$ label claim was procured from local pharmacy. Acetonitrile and water used are of HPLC grade.

\section{Instrumentation:}

The chromatographic separations were performed using HPLC-Waters alliance (Model-2695) consisting of an in-built auto sampler, a column oven and 2996 PDA detector. The data was acquired through Empower-2-software. The column used was Inertsil ODS, C18 $(150 \times 4.6 \mathrm{~mm}) 5 \mu \mathrm{m}$. Meltronics sonicator was used for enhancing dissolution of the compounds. Elico $\mathrm{pH}$ meter was used for adjusting the $\mathrm{pH}$ of buffer solution. All weighing was done on Sartorious balance (model AE-160).

\section{Chromatographic conditions:}

The mobile phase consists of Buffer: Acetonitrile in the ratio of 55:45 \%v/v. The mobile phase was pumped from solvent reservoir in the ratio of $55: 45 \% \mathrm{v} / \mathrm{v}$ to the column in the flow rate of $1.0 \mathrm{ml} / \mathrm{min}$ whereas run time set was $8 \mathrm{~min}$. The separation was performed on Inertsil ODS, C18 $(150 \times 4.6 \mathrm{~mm}) 5 \mu \mathrm{m}$., and the column was maintained the temperature of $30^{\circ} \mathrm{C}$ and the volume of each injection was $10 \mu \mathrm{l}$. Prior to injection, the column was equilibrated for at least $30 \mathrm{~min}$ with mobile phase flowing through the system. The eluents were monitored at $258 \mathrm{~nm}$. The optimized chromatographic conditions were shown in Table-1. 
Table-1: Optimized Chromatographic conditions and system suitability parameters for proposed HPLC method for Pimecrolimus

\begin{tabular}{cll}
\hline S.No. & \multicolumn{1}{c}{ Parameter } & \multicolumn{1}{c}{ Chromatographic conditions } \\
\hline 1. & Instrument & $:$ Waters 2695, High performance Liquid Chromatography \\
2. & Flow rate & $:$ : $1 \mathrm{ml} / \mathrm{min}$ \\
3. & Column & $:$ Inertisil ODS C18, 150 x $4.6 \mathrm{~mm}, 5 \mu$. \\
4. & Detector wave length & $:$ : $228 \mathrm{~nm}$ \\
5. & Column temperature & $: 30^{\circ} \mathrm{C}$ \\
6. & Injection volume & $: 10 \mu \mathrm{L}$ \\
7. & Run time & $:: 8 \mathrm{~min}$ \\
8. & Diluent & $:$ Water: Acetonitrile $(50: 50)$ \\
9. & Mode of separation & $:$ Isocratic mode \\
\hline
\end{tabular}

\section{Preparation of buffer solution:(pH-3.0)}

Accurately weighed 1.36 gm of Potassium dihyrogen Ortho phosphate was transferred into $1000 \mathrm{ml}$ of volumetric flask, to this about $900 \mathrm{ml}$ of milli-Q water was added and degassed by sonication and finally made up the volume with water then $\mathrm{pH}$ adjusted to 3.0 with dil. orthophosphoric acid solution.

\section{Preparation of mobile phase:}

Buffer and Acetonitrile taken in the ratio 55:45. Filtered through $0.45 \mu$ filter under vacuum filtration.

\section{Preparation of standard solution: $(20 \mathrm{ppm}$ Pimecrolimus)}

Accurately weighed and transferred $10 \mathrm{mg}$ of Pimecrolimus working standard into a $50 \mathrm{ml}$ clean dry volumetric flask, to this added 30 $\mathrm{ml}$ of diluent, sonicated for 30 minutes and made up the volume up to the mark with diluent and mixed. From the above stock solution, $1 \mathrm{ml}$ was pipetted out in to a $10 \mathrm{ml}$ volumetric flask and then made up the volume up to the mark with diluent.

\section{Preparation of sample solution:}

Accurately weighed about 1 gram of sample from tube (which is equivalent to $10 \mathrm{mg}$ ) in to a $50 \mathrm{ml}$ volumetric flask, $30 \mathrm{ml}$ of diluent was added and sonicated for $30 \mathrm{~min}$, further the volume made up to the mark with diluent, mixed and filtered. From the filtered solution $1 \mathrm{ml}$ was pipetted out into a $10 \mathrm{ml}$ volumetric flask and made up to $10 \mathrm{ml}$ with diluent.

Label Claim:1\% w/w

HPLC Chromatograms of Standard, Sample and Placebo were shown in Fig. 2-4.

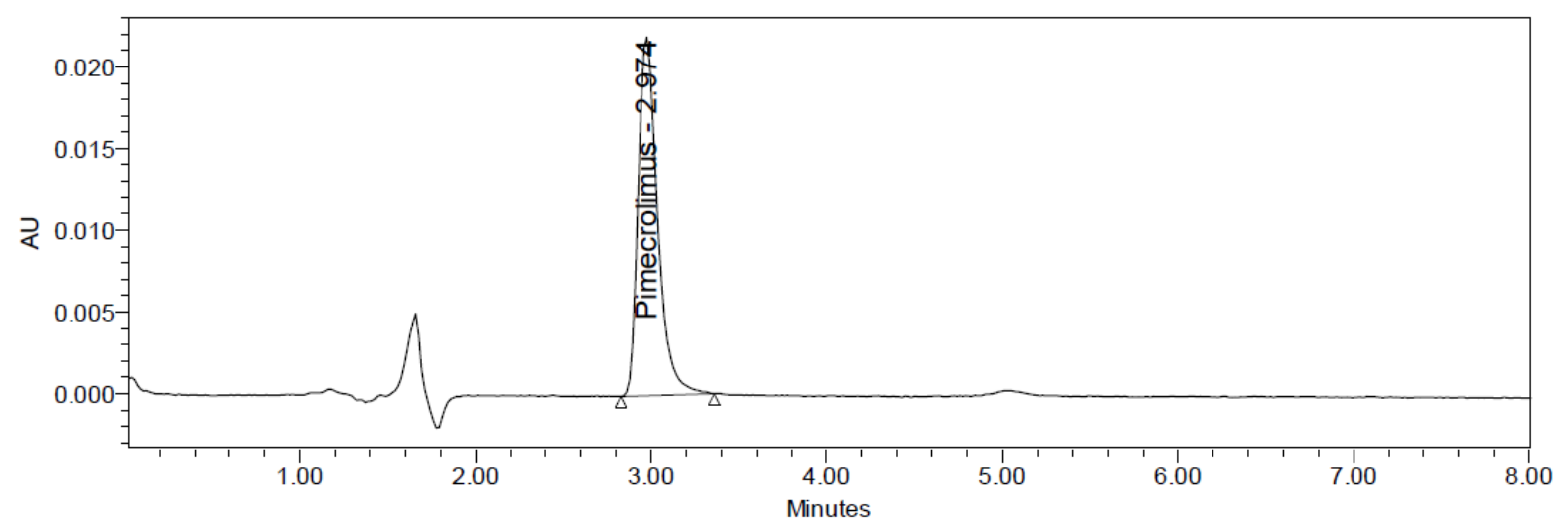

Fig. 2: HPLC Chromatogram of Standard 


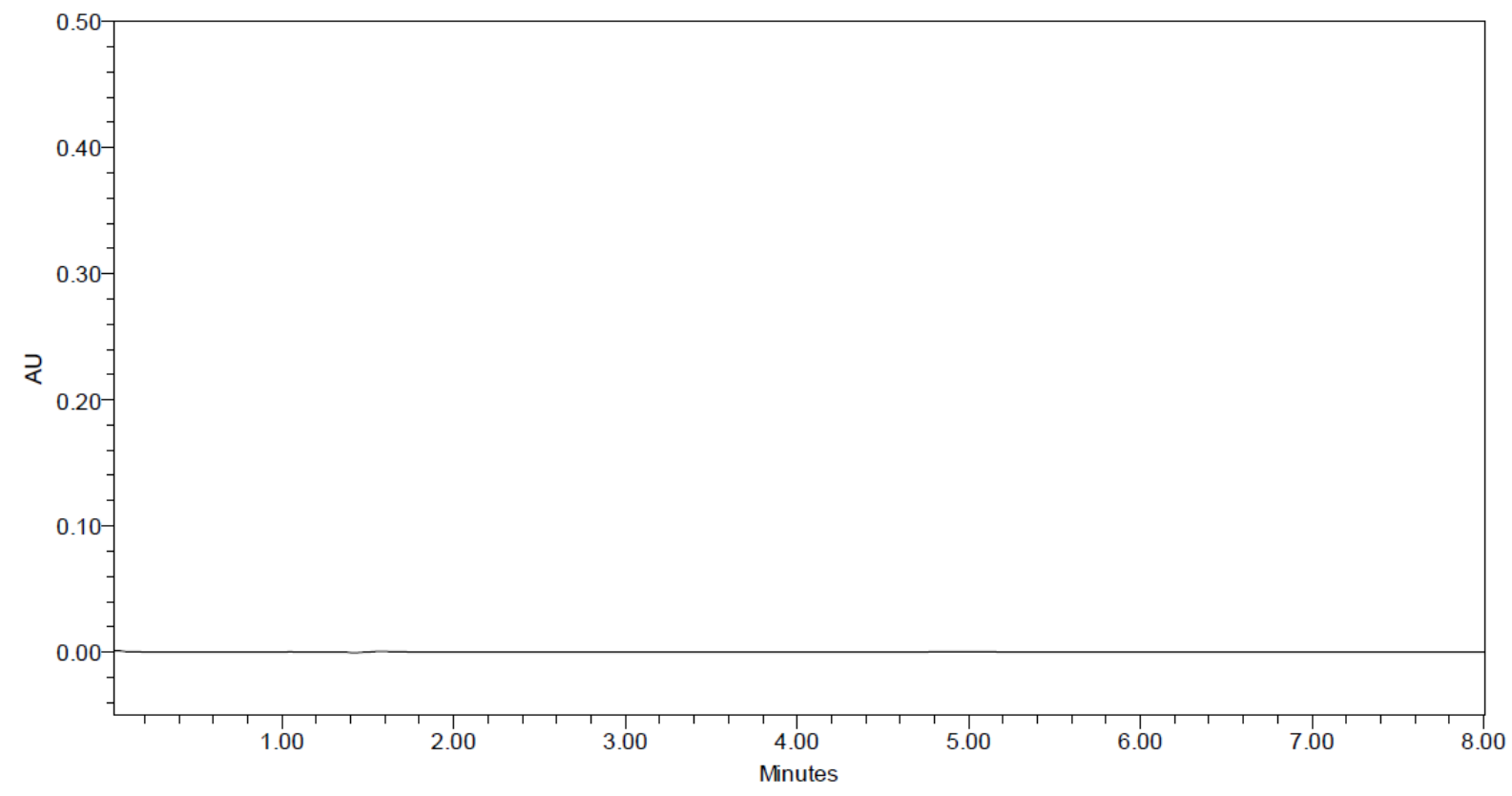

Fig. 3: HPLC Chromatogram of Placebo

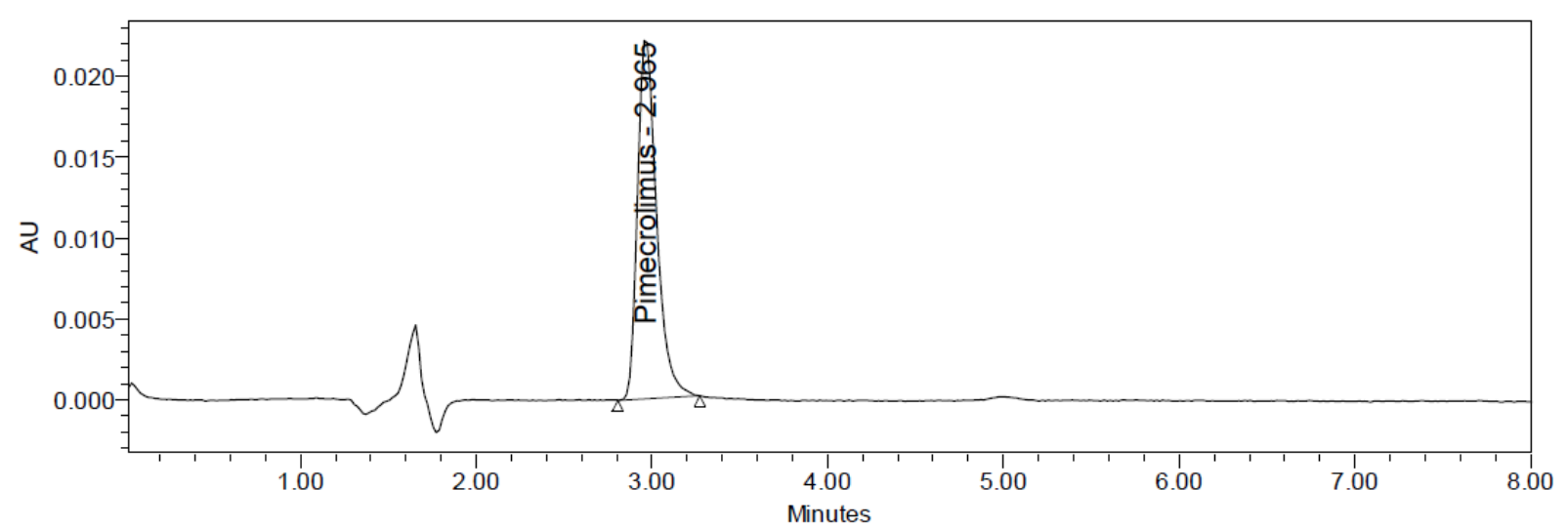

Fig. 4: HPLC Chromatogram of Sample

\section{Validation of Proposed method:}

The developed method was validated as per the ICH (International Conference on Harmonization) Q2-R1 guidelines with respect to System suitability, Precision, Specificity, Forced degradation studies, Linearity, Accuracy, Limit of detection and Limit of quantification.

\section{Linearity:}

Aliquots of $0.25,0.5,0.75,1.0,1.25$ and $1.5 \mathrm{ml}$ were taken from stock solution of concentration $200 \mu \mathrm{g} / \mathrm{ml}$ Pimecrolimus and then diluted to $10 \mathrm{ml}$ with diluent. Such that the final concentrations were in the range 5 ppm - 30 ppm for Pimecrolimus. Volume of $10 \mu \mathrm{l}$ of each sample was injected in five times for each concentration level and calibration curve was constructed by plotting the peak area versus drug concentration. A linear relationship between peak area vs. concentration was observed in the range of study. The observations and calibration curve were shown in Table- 2 and Fig. 5.

Table-2: Linearity

\begin{tabular}{ccc}
\hline S.No. & $\begin{array}{c}\text { Conc. of } \\
\text { Pimecrolimus } \\
\text { in ppm }\end{array}$ & $\begin{array}{c}\text { Pimecrolimus } \\
\text { Area }\end{array}$ \\
\hline 1 & 5 & 43132 \\
2 & 10 & 85331 \\
3 & 15 & 125878 \\
4 & 20 & 168754 \\
5 & 25 & 211104 \\
6 & 30 & 254738 \\
\hline
\end{tabular}




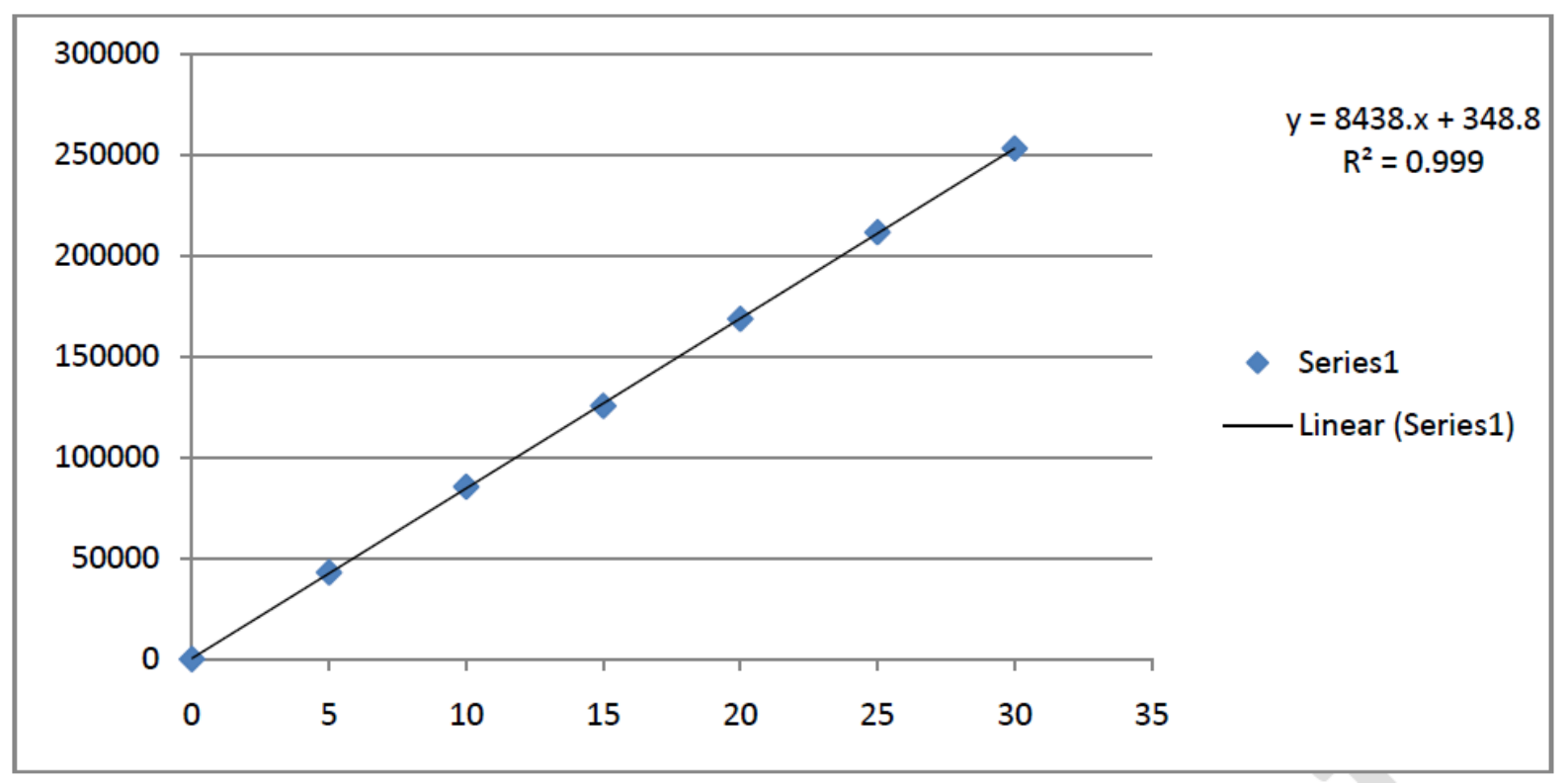

Fig. 5: Linearity of Pimecrolimus

\section{System precision:}

Precision is the measure of closeness of the data values to each other for a number of measurements under the same analytical conditions. Standard solution of $20 \mathrm{ppm}$ Pimecrolimus were prepared as per test method and injected for 6 times. Results are shown in Table-3.

\section{Table-3: System precision}

\begin{tabular}{cc}
\hline $\begin{array}{c}\text { Injection } \\
\text { No. }\end{array}$ & Area \\
\hline $\mathbf{1}$ & 171046 \\
$\mathbf{2}$ & 168012 \\
$\mathbf{3}$ & 168102 \\
$\mathbf{4}$ & 170218 \\
$\mathbf{5}$ & 167443 \\
$\mathbf{6}$ & 169879 \\
\hline AVG & 169117 \\
S.D & 1453.8 \\
\%RSD & 0.86 \\
\hline
\end{tabular}

\section{Precision:}

Intraday and interday precision study of Pimecrolimus was carried out by estimating response for 6 times on the same day and on consecutive days for the concentration of 20 ppmPimecrolimus. The percent relative standard deviation (\%RSD) was calculated which was within the acceptable criteria of not more than 2 . The results were shown in Table-4A and 4B.
Table-4: Precision Table-4A: Intra-day precision

\begin{tabular}{cc}
\hline $\begin{array}{c}\text { Sample } \\
\text { preparation }\end{array}$ & Assay \\
\hline Sample-1 & 99.55 \\
Sample-2 & 100.32 \\
Sample-3 & 99.50 \\
Sample-4 & 99.83 \\
Sample-5 & 100.62 \\
Sample-6 & 99.39 \\
\hline AVG & 99.87 \\
S.D & 0.497 \\
\%RSD & 0.50 \\
\hline
\end{tabular}

Table-4B: Inter-day precision

\begin{tabular}{cc}
\hline $\begin{array}{c}\text { Sample } \\
\text { preparation }\end{array}$ & Assay \\
\hline Sample-1 & 98.44 \\
Sample-2 & 99.19 \\
Sample-3 & 98.38 \\
Sample-4 & 98.71 \\
Sample-5 & 99.49 \\
Sample-6 & 98.27 \\
\hline AVG & 98.75 \\
S.D & 0.491 \\
\%RSD & 0.50 \\
\hline
\end{tabular}

\section{Accuracy (Recovery studies):}

To determine the accuracy in sample preparation, method of standard additions was made for measuring the recovery of the drug. A fixed amount of sample was taken and standard drug was added at 50\%, 100\% and $150 \%$ levels. The results were analyzed and the results were found to be within the limits. 
The accuracy was expressed as the percentage of the analyte recovery.
The results were shown in Table-5.

Table-5: Accuracy

\begin{tabular}{cccc}
\hline \% Concentration & $\begin{array}{c}\text { Amount } \\
\text { Added } \\
(\boldsymbol{\mu g} / \mathbf{m l})\end{array}$ & $\begin{array}{c}\text { Amount } \\
\text { Found } \\
(\boldsymbol{\mu g} / \mathbf{m l})\end{array}$ & $\begin{array}{c}\text { \% } \\
\text { Recovery }\end{array}$ \\
\hline 50 & 10 & 9.91 & 99.11 \\
50 & 10 & 10.01 & 100.09 \\
50 & 10 & 10.17 & 101.66 \\
100 & 20 & 20.07 & 100.34 \\
100 & 20 & 19.92 & 99.59 \\
100 & 20 & 20.13 & 100.63 \\
150 & 30 & 30.12 & 100.40 \\
150 & 30 & 30.29 & 100.98 \\
150 & 30 & 29.84 & 99.46 \\
\hline & & Average: & 100.25 \\
& & SD: & 0.8 \\
& & RSD: & 0.8 \\
\hline
\end{tabular}

\section{Specificity:}

The specificity of the method was performed by injecting blank solution (without any sample) and then a drug solution of $10 \mu \mathrm{l}$ injected into the column, under Optimized chromatographic conditions, to demonstrate the separation of Pimecrolimus from any of the impurities, if present. As there was no interference of impurities, the method was found to be specific.

\section{Robustness:}

Robustness was carried by varying three parameters from the optimized chromato- graphic conditions such as making small changes in flow rate $( \pm 0.1 \mathrm{ml} / \mathrm{min})$, mobile phase composition $( \pm 5 \%)$ and column temperature $( \pm 5 \quad$ C). It was observed that the small changes in these operational parameters did not lead to changes of retention time of the peak of interest and the $\%$ RSD was not more than 2 . The degree of reproducibility of the results proven that the method is robust. The results were shown in Table-6.

Table-6: Robustness

\begin{tabular}{|c|c|c|c|c|c|c|c|}
\hline S.No. & Parameter & Optimized & Used & $\begin{array}{l}\text { Peak } \\
\text { Area }\end{array}$ & $\begin{array}{c}\text { Retention } \\
\text { Time }\end{array}$ & $\begin{array}{l}\text { Plate } \\
\text { count }\end{array}$ & $\begin{array}{l}\text { Tailing } \\
\text { Factor }\end{array}$ \\
\hline \multirow{3}{*}{1} & Flow Rate & \multirow{3}{*}{$1.0 \mathrm{ml} / \mathrm{min}$} & $0.9 \mathrm{ml} / \mathrm{min}$ & 186851 & 3.286 & 3944 & 1.37 \\
\hline & $( \pm 0.1$ & & $1.0 \mathrm{ml} / \mathrm{min}$ & 169117 & 2.970 & 3610 & 1.37 \\
\hline & $\mathrm{ml} / \mathrm{min}$ ) & & $1.1 \mathrm{ml} / \mathrm{min}$ & 169064 & 2.709 & 3494 & 1.34 \\
\hline \multirow{3}{*}{2} & Column & \multirow{3}{*}{$30 \mathrm{C}$} & $25^{\circ} \mathrm{C}$ & 189746 & 3.286 & 3925 & 1.40 \\
\hline & Temperature & & $30^{\circ} \mathrm{C}$ & 169117 & 2.970 & 3610 & 1.37 \\
\hline & $\left( \pm 5^{\circ} \mathrm{C}\right)$ & & $35^{\circ} \mathrm{C}$ & 155675 & 2.709 & 3471 & 1.37 \\
\hline \multirow{3}{*}{3} & \multirow{3}{*}{$\begin{array}{l}\text { Mobile phase } \\
\text { composition }\end{array}$} & \multirow{3}{*}{$\begin{array}{c}\text { Buffer : ACN } \\
55: 45 \mathrm{v} / \mathrm{v}\end{array}$} & $60: 40$ & 169064 & 2.950 & 3673 & 1.41 \\
\hline & & & $55: 45$ & 169117 & 2.970 & 3610 & 1.37 \\
\hline & & & $50: 50$ & 185273 & 2.959 & 3620 & 1.41 \\
\hline
\end{tabular}

\section{Limit of Detection and Limit of} Quantification:

LOD and LOQ were calculated using the following formula $\mathrm{LOD}=3.3(\mathrm{SD}) / \mathrm{S}$ and $\mathrm{LOQ}=$ 10 (SD)/S, where SD = standard deviation of response (peak area) and $S=$ slope of the calibration curve. Limit of Detection and Limit of Quantification were found to be $0.06 \mu \mathrm{g} / \mathrm{ml}$ and $0.19 \mu \mathrm{g} / \mathrm{ml}$ respectively for Pimecrolimus as per ICH Q2-R1 guidelines. The results were shown in Table-7. 
Table-7: Characteristics of HPLC method

\begin{tabular}{clc}
\hline Drug & Parameters defined & $\begin{array}{c}\text { Obtained } \\
\text { value }\end{array}$ \\
\hline Pimecrolimus & Linearity range $(\mathrm{ppm})$ & $5-30 \mathrm{ppm}$ \\
& Regression coefficient $\left(\mathrm{r}^{2}\right)$ & 0.999 \\
& Intercept & 349 \\
& Slope & 8438 \\
& LOD $(\mathrm{ppm})$ & 0.06 \\
& LOQ $(\mathrm{ppm})$ & 0.19 \\
& Tailing factor & 1.39 \\
& Plate count & 3536 \\
\hline
\end{tabular}

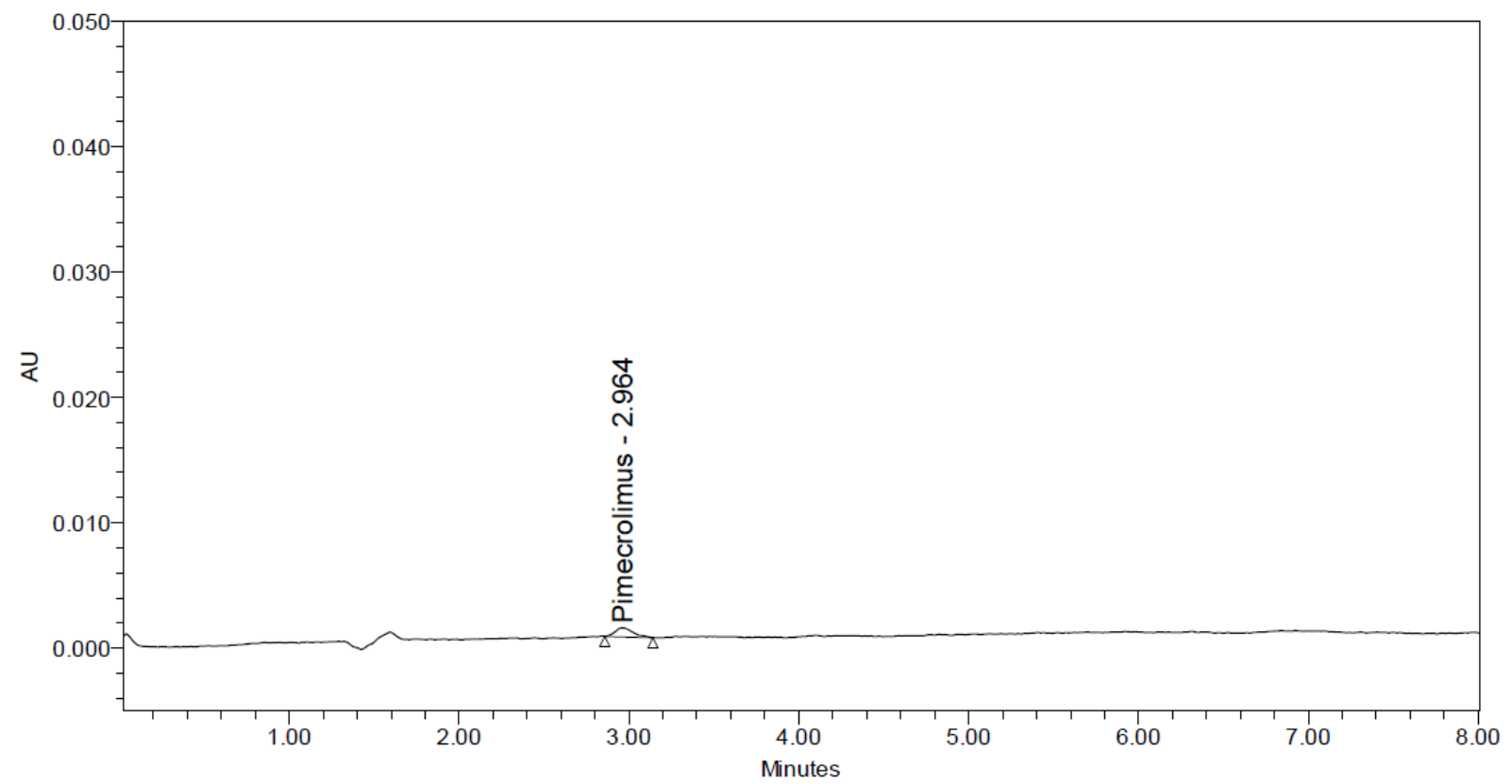

Fig. 6: HPLC Chromatogram of LOD

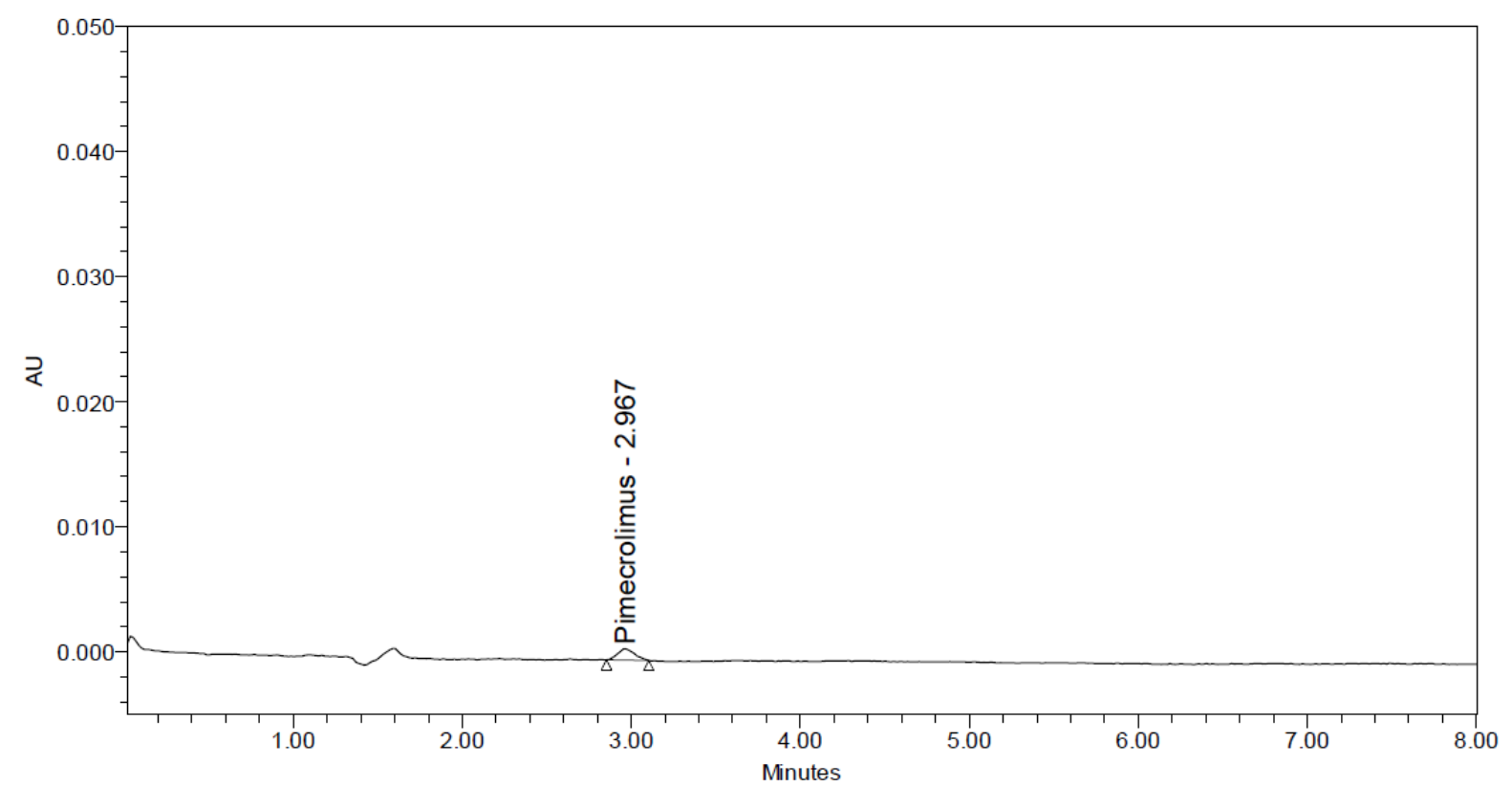

Fig. 7: HPLC Chromatogram of LOQ

System suitability:

The system suitability was determined by making six replicate injections from freshly prepared standard solutions. The observed
RSD values were well within usually accepted limits $(\leq 2 \%)$. Theoretical plates, tailing factor ofPimecrolimus were determined. The results 
are all within acceptable limits summarized in Table-7.

\section{Forced Degradation Studies:}

Forced degradation studies were performed to demonstrate the optimized method is stability indicating. To prove the method which can be able to measure accurately active pharmaceutical ingredient in presence of degradants which are expected to be formed during different types of degradations applied to the drug sample.

For forced degradation analysis, aliquots of stock $(20 \mu \mathrm{g} / \mathrm{ml})$ were separately treated with $1 \mathrm{ml}$ of $1 \mathrm{~N} \mathrm{HCl}$ (Acid stability), $1 \mathrm{ml}$ of $1 \mathrm{~N}$ $\mathrm{NaOH}$ (Alkaline stability), $1 \mathrm{ml}$ of $20 \% \mathrm{H}_{2} \mathrm{O}_{2}$
(Oxidative degradation), exposure of standard drug solution at $105^{\circ} \mathrm{C}$ for $6 \mathrm{hrs}$ (dry heat degradation), photo stability degradation (exposure of drug at 200 watt $/ \mathrm{m}^{2}$ ) and neutral degradation (refluxing with water at $60^{\circ} \mathrm{C}$ for 6 hours. Stability of these samples was compared with fresh sample on the day of analysis. The HPLC chromatograms of degraded products show no interference at the analyte peaks, hence the method was specific and stability indicating. The results were shown in Table-8 and the chromatograms were shown in figures $8 \mathrm{~A}-8 \mathrm{~F}$. The detailed degradation for each condition is as follows:

Table-8: Forced Degradation Studies

\begin{tabular}{ccccccc}
\hline S.No. & Injection & \%Assay & \%Degradation & $\begin{array}{c}\text { Purity } \\
\text { Angle }\end{array}$ & $\begin{array}{c}\text { Purity } \\
\text { Threshold }\end{array}$ & $\begin{array}{c}\text { Purity } \\
\text { Flag }\end{array}$ \\
1 & $\begin{array}{c}\text { Controlled } \\
\text { sample }\end{array}$ & 99.87 & -- & 0.763 & 1.342 & No \\
2 & $\begin{array}{c}\text { Acid } \\
\text { Degradation }\end{array}$ & 92.27 & 7.60 & 0167 & 0.388 & No \\
3 & $\begin{array}{c}\text { Base } \\
\text { Degradation }\end{array}$ & 97.01 & 2.86 & 0.221 & 0.341 & No \\
4 & $\begin{array}{c}\text { Peroxide } \\
\text { Degradation }\end{array}$ & 94.50 & 5.37 & 0.163 & 0.330 & No \\
5 & $\begin{array}{c}\text { Thermal } \\
\text { Degradation }\end{array}$ & 97.68 & 2.19 & 0.182 & 0.326 & No \\
6 & $\begin{array}{c}\text { UV } \\
7\end{array}$ & 98.28 & 0.59 & 0.182 & 0.330 & No \\
\hline
\end{tabular}

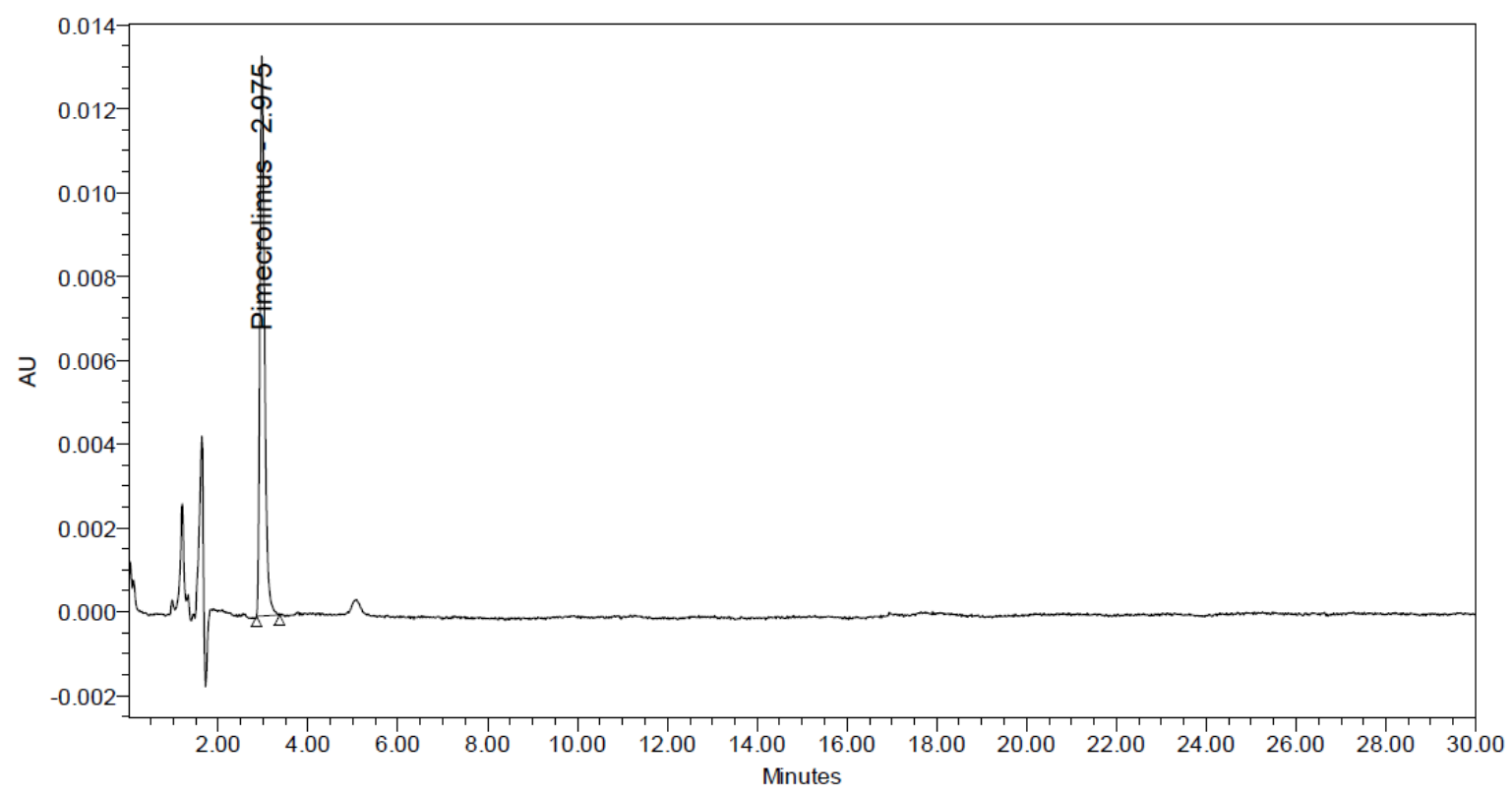

Fig. 8A: Acid Degradation 


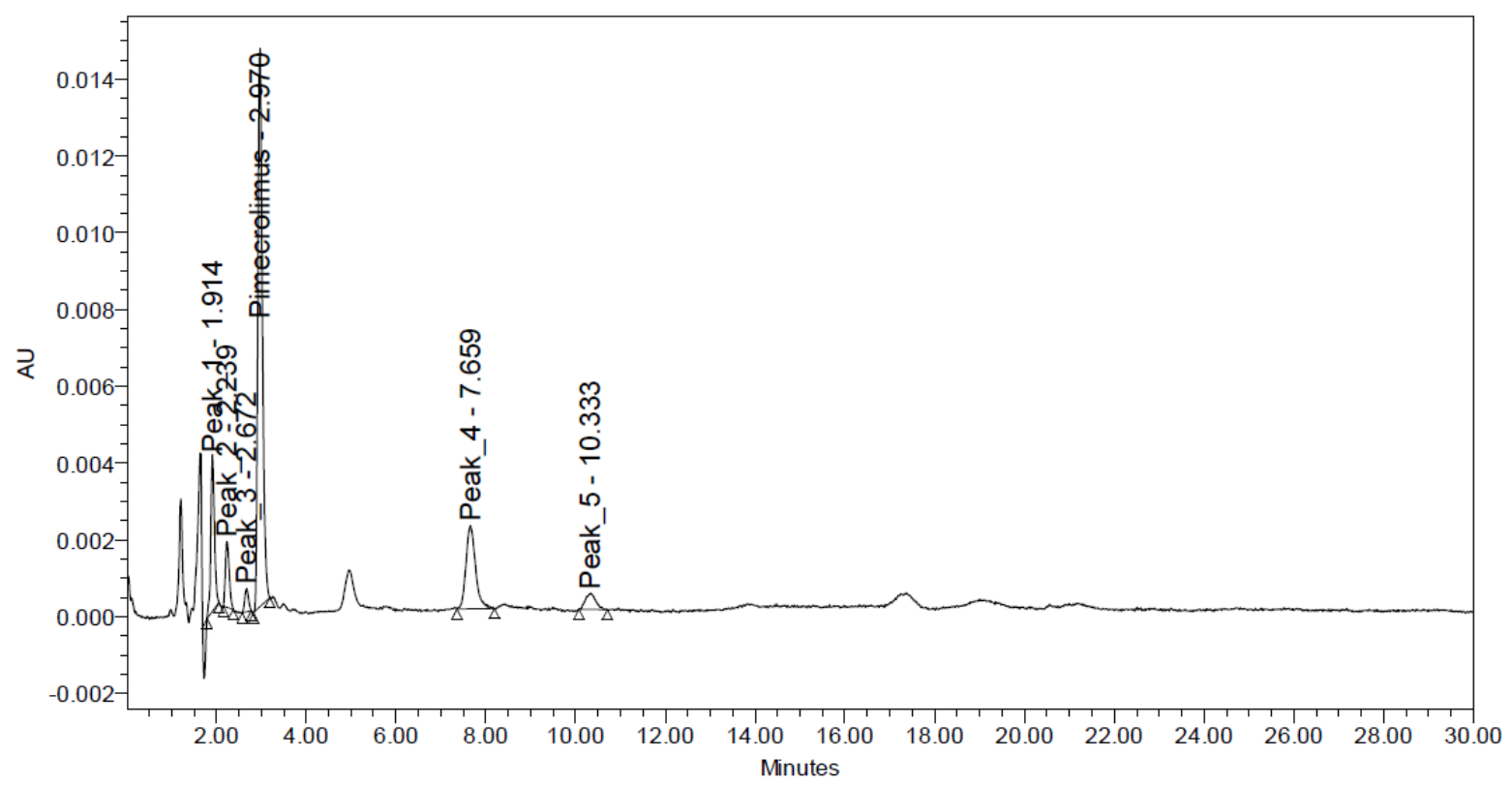

Fig. 8B: Base Degradation

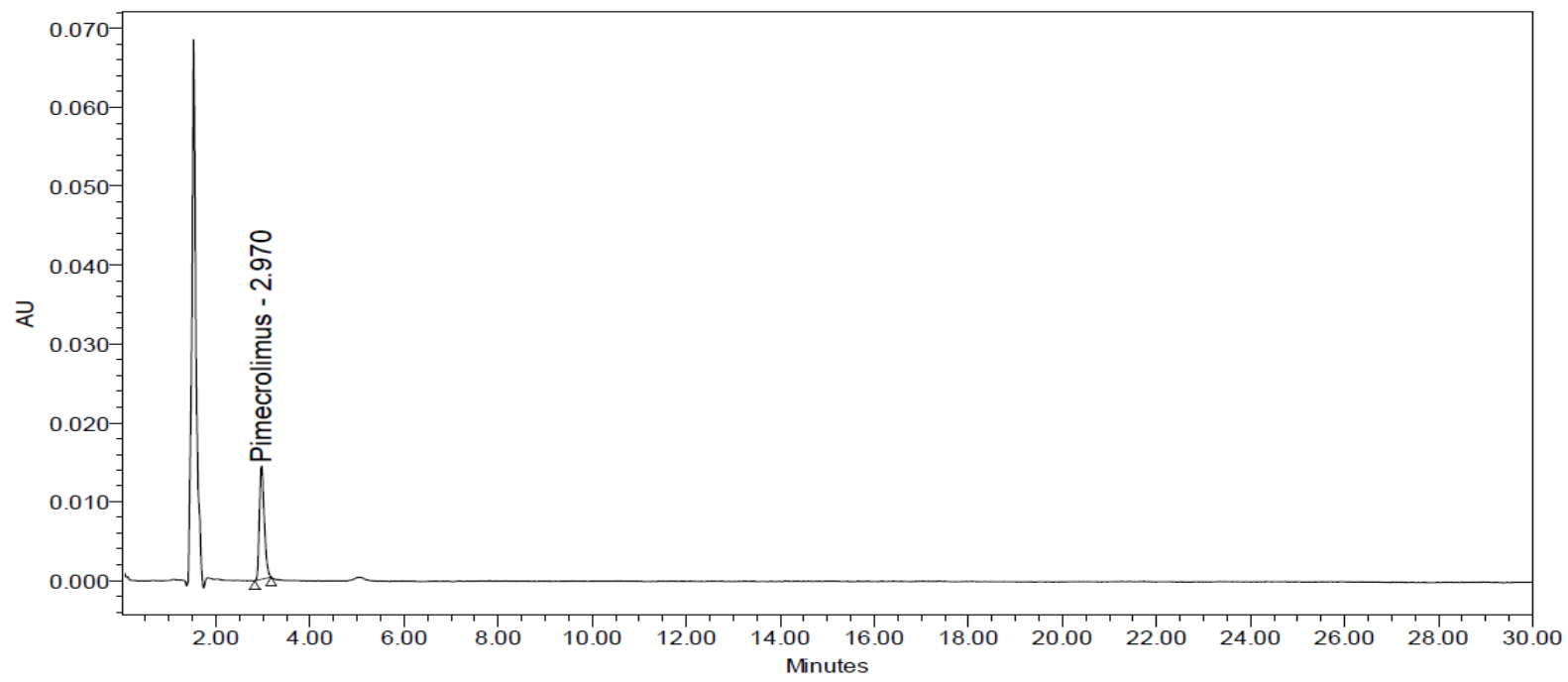

Fig. 8C: Peroxide Degradation

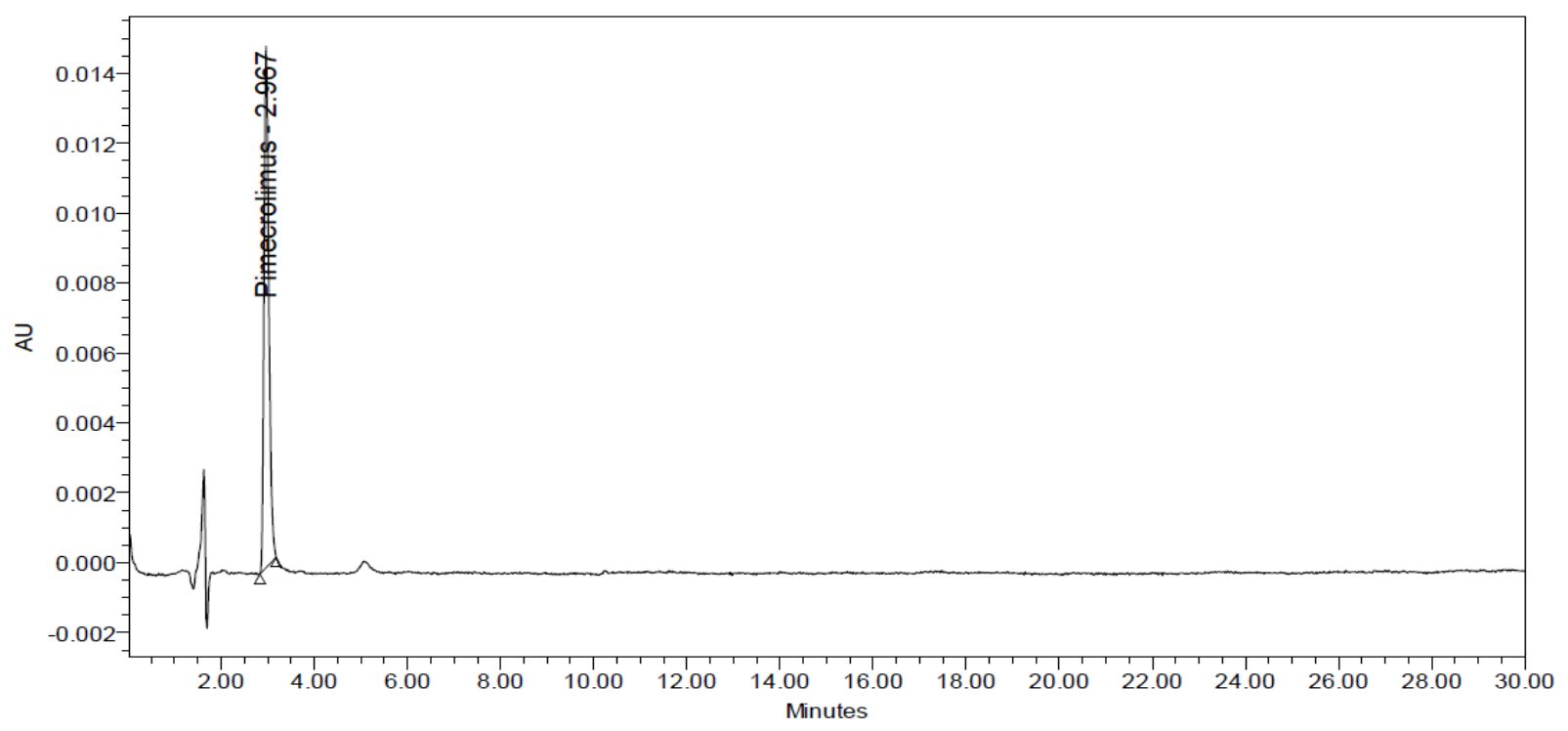

Fig. 8D: Thermal Degradation 


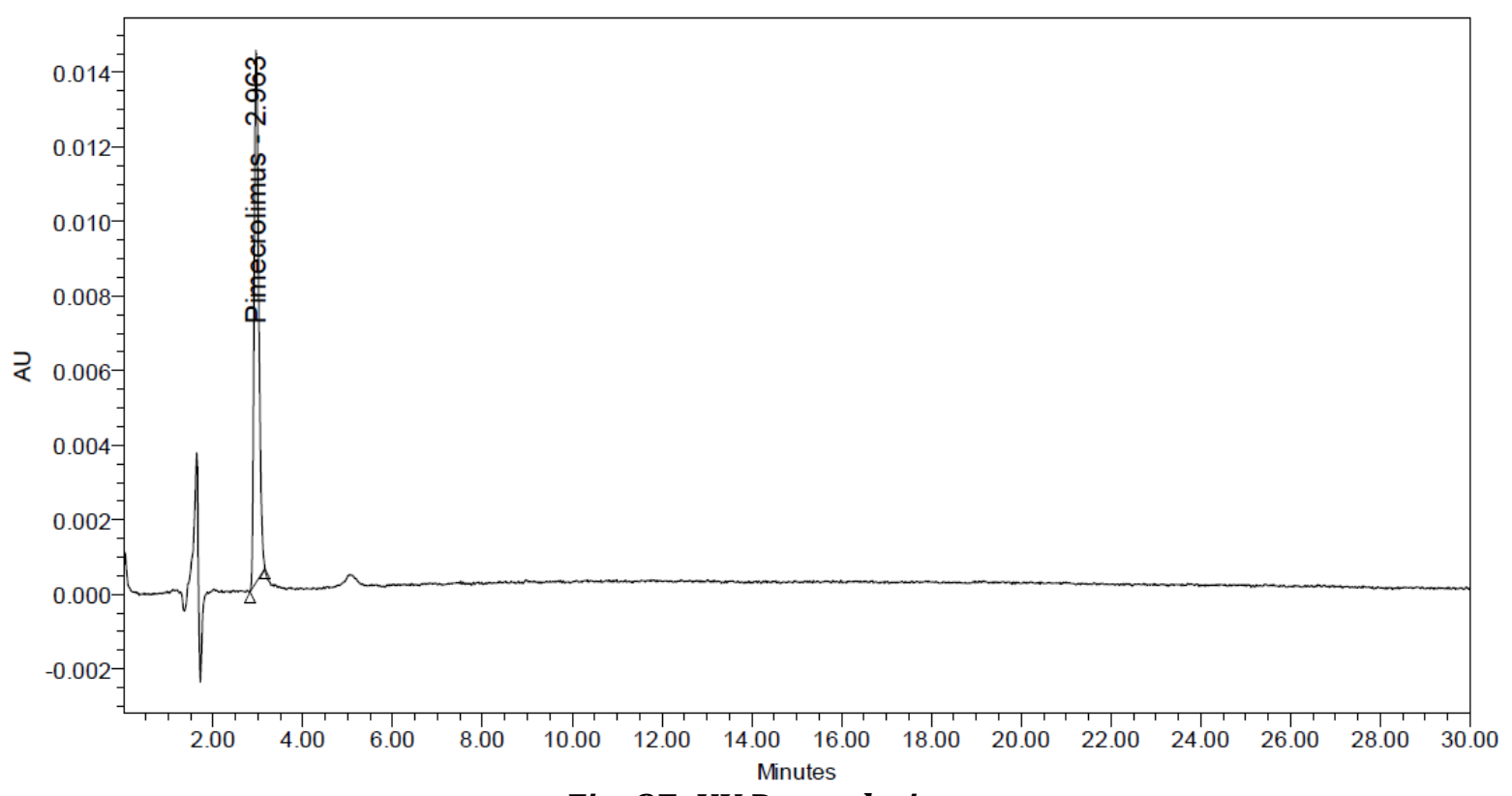

Fig. 8E: UV Degradation

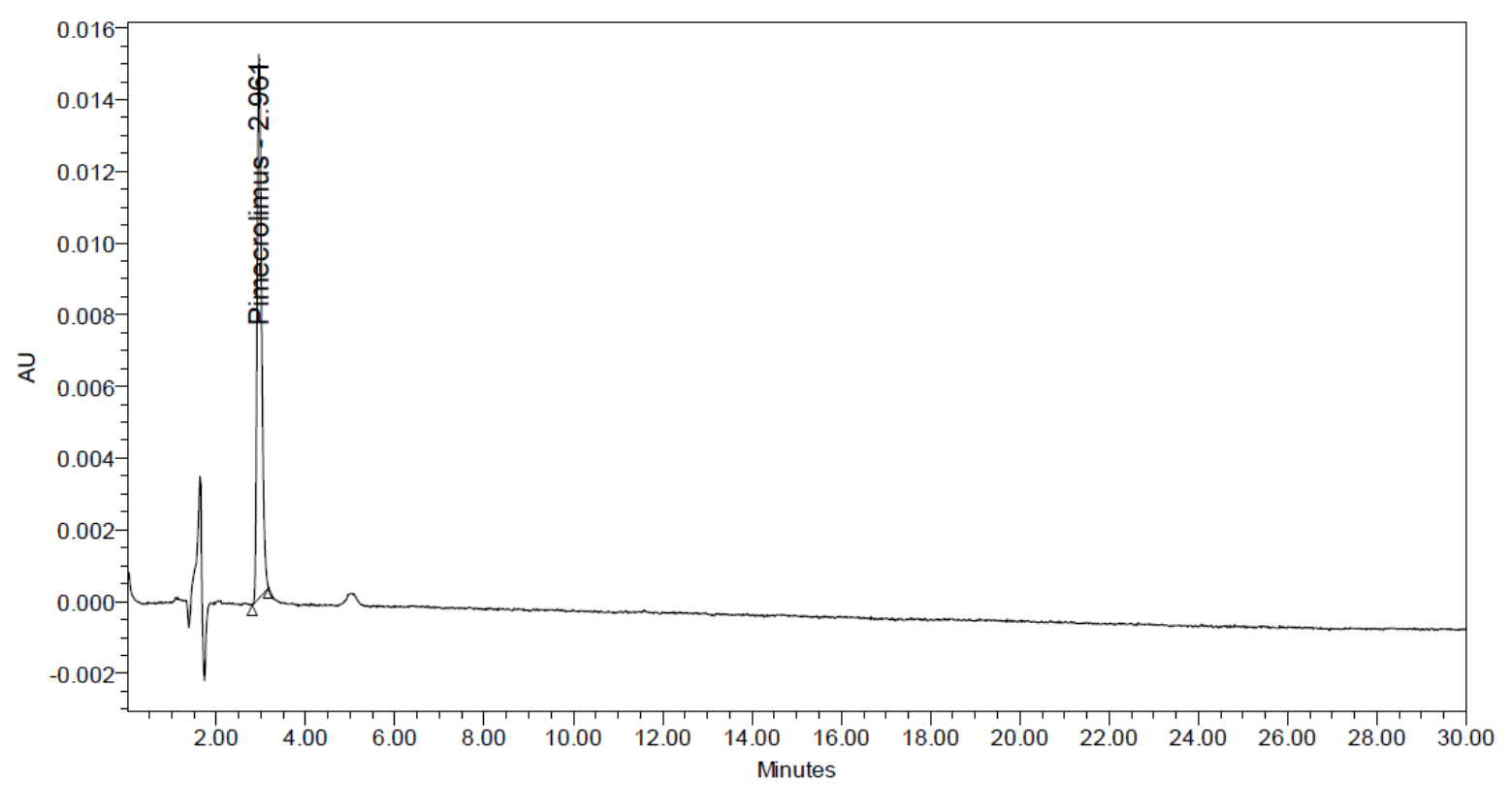

Fig. 8F: Water Degradation

\section{Oxidation:}

To $1 \mathrm{ml}$ of stock solution of Pimecrolimus, 1 $\mathrm{ml}$ of 20\% hydrogen peroxide (H2O2) was added separately. The solutions were kept for $30 \mathrm{~min}$ at $60^{\circ} \mathrm{c}$. For HPLC study, the resultant solution was diluted to obtain $20 \mu \mathrm{g} / \mathrm{ml}$ solution and $10 \mu \mathrm{l}$ were injected into the system and the chromatograms were recorded to assess the stability of sample.

\section{Acid DegradationStudies:}

To $1 \mathrm{ml}$ of stock solution of Pimecrolimus, 1 $\mathrm{ml}$ of $1 \mathrm{~N}$ Hydrochloric acid was added and refluxed for $30 \mathrm{mins}$ at $60^{\circ} \mathrm{c}$. Neutralised with $1 \mathrm{ml}$ of $1 \mathrm{~N} \mathrm{NaOH}$ solution. The resultant solution was diluted to obtain $20 \mu \mathrm{g} / \mathrm{ml}$ solution and $10 \mu \mathrm{l}$ solutions were injected into the system and the chromatograms were recorded to assess the stability of sample.

\section{AlkaliDegradationStudies:}

To $1 \mathrm{ml}$ of stock solution of Pimecrolimus, 1 $\mathrm{ml}$ of $1 \mathrm{~N}$ sodium hydroxide was added and refluxed for 30 mins at $60^{\circ} \mathrm{C}$. Neutralized with $1 \mathrm{ml}$ of $1 \mathrm{~N}$ Hydrochloric acid solution. The resultant solution was diluted to obtain 20 $\mu \mathrm{g} / \mathrm{ml}$ solution and $10 \mu \mathrm{l}$ were injected into the system and the chromatograms were recorded to assess the stability of sample.

\section{DryHeatDegradationStudies:}

The standard drug solution was placed in oven at $105^{\circ} \mathrm{C}$ for $6 \mathrm{hr}$ to study dry heat degradation. For HPLC study, the resultant solution was diluted to $20 \mu \mathrm{g} / \mathrm{ml}$ solution and 
$10 \mu \mathrm{l}$ were injected into the system and the chromatograms were recorded to assess the stability of the sample.

\section{PhotoStabilitystudies:}

The photochemical stability of the drug was also studied by exposing the stock solution to UV Light by keeping the beaker in UV Chamber for 7 days or 200 Watt hours $/ \mathrm{m}^{2}$ in photo stability chamber. For HPLC study, the resultant solution was diluted to obtain 20 $\mu \mathrm{g} / \mathrm{ml}$ solution and $10 \mu \mathrm{l}$ were injected into the system and the chromatograms were recorded to assess the stability of sample.

\section{NeutralDegradationStudies:}

Stress testing under neutral conditions was studied by refluxingthedruginwaterfor $6 \mathrm{~h} \mathrm{r}$ atatemperature of 60 C. For HPLC study, the resultant solution was diluted to 20 $\mu \mathrm{g} / \mathrm{ml}$ solution and $10 \mu \mathrm{l}$ were injected intothesystemandthechromatogramswerereco rded toassessthestabilityofthesample.

\section{RESULTS AND DISCUSSION:}

The main aim for development of chromatographic method was to get reliable method for quantification of Pimecrolimus from bulk and pharmaceutical dosage form. Different chromatographic conditions were employed for the analysis of the Pimecrolimus in both bulk and pharmaceutical dosage form. Finally the analysis was performed by using Phosphate Buffer: Acetonitrile in the ratio of $55: 45 \% \mathrm{v} / \mathrm{v}$ at a flow rate $1.0 \mathrm{ml} / \mathrm{min}$. Samples were analysed at $258 \mathrm{~nm}$ at an injection volume of $10 \mu \mathrm{l}$ and separation was carried by using Inertsil ODS, C18, (150 x $4.6 \mathrm{~mm}, 5 \mu)$., column. The retention time and tailing factor were calculated. The retention time of Pimecrolimus was found to be 2.974 minutes. The proposed column was selected which gave a sharp and symmetrical peak with 1.39 tailing factor and theoretical plates of 3536 for Pimecrolimus. The calibration curve was linear over the concentration range of 5-30 (ppm) ofPimecrolimus. Six different concentrations of Pimecrolimus in the given range were prepared and injected into HPLC. The linearity of the method was statistically confirmed. RSD values for accuracy and precision studies obtained were less than $2 \%$ which revealed that developed method was accurate and precise. The slope (m) and intercept (c) obtained were shown in the table-7. The system suitability parameters were given in Table- 7 .
Forced degradation studies concluded that the all the degradant peaks obtained during degradation were well resolved from Pimecrolimus. And the peak purity was passed i.e. purity angle was less than purity threshold as per Empower-2 software. Hence the method is found to be stability indicating.

Therefore proposed validated stability indicating method was successfully applied to determine Pimecrolimus in Bulk and Pharmaceutical dosage form.

\section{CONCLUSION:}

The developed method is accurate, simple, rapid and selective \& proved to be stability indicating for the estimation of Pimecrolimus in bulk and pharmaceutical dosage form. The sample preparation is simple, the analysis time is short and the elution is by isocratic method. The retention time of Pimecrolimus was found to be 2.974 minutes. The excipients of the commercial sample analyzed did not interfere in the analysis, which proved the specificity of the method for these drugs. Forced degradation studies of different conditions shows that all the degradants were well resolved from this main drug peak and able to quantify the Pimecrolimus in presence of degradants \& excipients which proved that the method is found to be stability indicating. Hence the proposed method can be conveniently adopted for the routine quality control analysis in the bulk and pharmaceutical formulations.

\section{ACKNOWLEDGEMENT:}

The authors gratefully acknowledge Spectrum Pharma Research Solutions, Hyderabad, India for providing necessary facilities to carry out this research work.

\section{REFERENCES:}

1. Allen BR, Lakhanpaul M, Morris A, Lateo S, Davies T, Scott G, Cardno M, Ebelin ME, Burtin P, Stephenson TJ (2003). "Systemic exposure, tolerability, and efficacy of Pimecrolimus cream 1\% in atopic dermatitis patients". Arch Dis Child88 (11): 969-973

2. Meingassner JG, Kowalsky E, Schwendinger H, Elbe-Bürger A, Stütz A. "Pimecrolimus does not affect Langerhans cells in murine epidermis". Br J Dermatol, 2003,149 (4): 853-857.

3. Billich A, Aschauer H, Aszódi A, Stuetz A. "Percutaneous absorption of drugs used in atopic eczema: Pimecrolimus permeates less through skin than 
corticosteroids and tacrolimus". Int $J$ Pharm, 2004;269 (1): 29-35.

4. Firooz A, Solhpour A, Gorouhi F, Daneshpazhooh M, Balighi K, Farsinejad K, Rashighi-Firoozabadi M, Dowlati Y. "Pimecrolimus cream, 1\%, vs hydrocortisone acetate cream, $1 \%$, in the treatment of facial seborrheic dermatitis: a randomized, investigator-blind, clinical trial". Archives of Dermatology, 2006; 142 (8): 1066-1067.

5. Firooz A, Solhpour A, Gorouhi F, Daneshpazhooh M, Balighi K, Farsinejad K, Rashighi-Firoozabadi M, Dowlati Y. "Pimecrolimus cream, 1\%, vs hydrocortisone acetate cream, $1 \%$, in the treatment of facial seborrheic dermatitis: a randomized, investigator-blind, clinical trial". Archives of Dermatology, 2006; 142 (8): 1066-1067.

6. Boone B, Ongenae K, Van Geel N, Vernijns S, De Keyser S, Naeyaert JM. "Topical Pimecrolimus in the treatment of vitiligo". Eur J Dermatol, 2007; 17 (1): 55-61.

7. Kreuter A, Sommer A, Hyun J, Bräutigam $\mathrm{M}$, Brockmeyer $\mathrm{NH}$, Altmeyer $\mathrm{P}$, Gambichler T. "1\% Pimecrolimus, $0.005 \%$ calcipotriol, and $0.1 \%$ betamethasone in the treatment of intertriginous psoriasis: a double-blind, randomized controlled study". Arch Dermatol, 2006; 142 (9): 1138-1143.

8. Jacobi A, Braeutigam M, Mahler V, Schultz E, Hertl M. "Pimecrolimus 1\% cream in the treatment of facial psoriasis: a 16week open-label study". Dermatology, 2008; 216 (2): 133-136.

9. Scheinfeld N. "The use of topical tacrolimus and Pimecrolimus to treat psoriasis: a review". Dermatol Online J., 2004; 10 (1): 3.
10. N H Cox and Catherine H Smith. "Advice to dermatologists re topical tacrolimus" (DOC). Therapy Guidelines Committee. British Association of Dermatologists; December 2002.

11. Berger TG, Duvic M, Van Voorhees AS, VanBeek MJ, Frieden IJ; American Academy of Dermatology Association Task Force. "The use of topical calcineurin inhibitors in dermatology: safety concerns Report of the American Academy of Dermatology Association Task Force". J Am Acad Dermatol, 2006; 54 (5): 818-823.

12. Novartis Pharma AG, Basel, Switzerland (M.Z., F.W., S.H., A.G.Z., U.G., J.-P.B., A.S., S.B., T.M.) and Novartis Institutes for Bio Medical Research, Basel, Switzerland (G.Z.) and Vienna, Austria (M.A.G.): Pimecrolimus: Absorption, Distribution, Metabolism, and Excretion in healthy volunteers after a single oral dose and supplementary investigations in vitro, The American Society for Pharmacology and Experimental Therapeutics, DMD, 2006, 34: 765-774.

13. Spergel JM, Leung DY. "Safety of topical calcineurin inhibitors in atopic dermatitis: evaluation of the evidence". Curr Allergy Asthma Rep, 2006; 6 (4): 270-274.

14. Eichenfield LF and Beck L, Elidel (pimecrolimus) cream 1\%: a nonsteroidal topical agent for the treatment of atopic dermatitis. J Allergy Clin Immunol, 2003; 111: 1153-1168.

15. http://www.drugs.com/drp/elidelcream 